\title{
CHEMICAL COMPOSITION, ANTIMICROBIAL, ANTIOXIDANT AND CYTOTOXIC ACTIVITIES OF EUCALYPTUS CHAPMANIANA GROWN IN IRAQ
}

\author{
${ }^{1}$ Ghassan Mohammad Sulaiman, \\ ${ }^{1}$ Thorria Radam Marzoog, ${ }^{1}$ Wasnaa Hatif Mohammed and ${ }^{2}$ Renzo Bagnati \\ ${ }^{1}$ Division of Biotechnology, Department of Applied Science, \\ University of Technology, Baghdad, Iraq \\ ${ }^{2}$ Department of Environmental Health Sciences, \\ IRCCS-Istituto di Ricerche Farmacologiche Mario Negri, Via La Masa 19, 20156 Milano, Italy
}

Received 2013-10-31; Revised 2013-11-13; Accepted 2013-12-27

\begin{abstract}
The chemical composition of the essential oils extracted from immature flowers, leaves and seeds of Eucalyptus chapmaniana grown in Iraq were analyzed for the first time by gas chromatography/mass spectrometry. Twenty-four different compounds were identified and the predominant compound is eucalyptol, which accounted for 59.9, 55.6 and $8.6 \%$ of total compounds, respectively. To asses the possible therapeutic uses of the extracts, their antioxidant properties were assessed via DPPH free radical scavenging. The extracts showed significant antioxidant and antimicrobial activities against Escherichia coli, Pseudomonas aeruginosa, Klebsiella pneumonia, Proteus volgaris, Staphylococcus aureus and Candida albicans. The cytoxicity of flower extract against the Human Leukemia (HL-60) cells was evaluated and the extracts significantly reduced the viability of HL-60 cells in a dose- and timedependent response relationship. The results indicated that essential oils from immature flowers are highly cytotoxic to HL-60 cells and that their antitumor potential was confirmed.
\end{abstract}

Keywords: Eucalyptus chapmaniana, Essential Oils, Antimicrobial, DPPH, HL-60

\section{INTRODUCTION}

The Myrtaceae family contains 133 genera and 3,800 species of trees and shrubs. This family can be found in temperate, subtropical and tropical regions and it is endemic in Australia, tropical America, Africa and Asia (Wilson et al., 2001). One important genera of Myrtaceae is Eucalyptus, which is a large genus of evergreen trees and shrubs containing approximately 700 species (Batish et al., 2008). Although most plants are native to Australia and Tasmania (Oyedeji et al., 1999), they have been successfully introduced worldwide and are cultivated in many other countries, including Iraq.

The leaves of the Eucalyptus species accumulate a very large number of secondary metabolites and yield hydro distilled essential oils that possess many biological properties, including antibacterial and antifungal activities (Cimanga et al., 2002; Ramezani et al., 2002; Sartorelli et al., 2007). In addition, the leaf and plant extracts of the Eucalyptus species themselves possess antibacterial and antifungal activities (Takahashi et al., 2004; Salari et al., 2006). Extracts and components isolated from several Eucalyptus species have been shown to possess cytotoxic and antitumor activities (Benyahia et al., 2005; Ashour, 2008).

Antioxidant agents are compounds that function as scavengers of reactive oxygen species or free radicals, which have important functions in energy production, synthesis of several biomolecules, phagocytosis and cell growth in living systems (Packer et al., 2008). An imbalance in the rate of production of free radicals or their removal via antioxidant defense mechanisms leads otechnology, Department of Applied Science, University of Technology, Baghdad, Iraq 
to a phenomenon referred to as oxidative stress. In diseases such as diabetes, cardiovascular diseases and cancer, an aggravated imbalance may occur during deleterious oxidation of biomolecules, which results in cell or tissue damage (Arts and Hollman, 2005; Jung et al., 2009; Wells et al., 2009).

Numerous investigations were performed on volatile components of essential oils from different species of Eucalyptus. Previous studies on the compositions of several Eucalyptus spp. leaves, flowers (Giamakis et al., 2001; Tsiri et al., 2003) and recently, stem and fruit essential oils have been reported (Marzoug et al., 2011). However, no previous studies on the chemistry and the antioxidant, antimicrobial and cytotoxic activities of essential oils from leaves, flowers and seeds of $E$. chapmaniana have been presented. In the current study the composition of essential oils obtained from adult leaves, immature flowers and seeds of E. chapmaniana collected in Iraq has been studied. The antioxidant, antimicrobial and cytotoxic activities of E. Chapmaniana were also investigated.

\section{MATERIALS AND METHODS}

\subsection{Chemicals}

All chemicals used were of analytical reagent grade. Penicillin and streptomycin were purchased from Bio Source International (Belgium). RPMI 1640, Fetal Bovine Serum (FBS), 3-(4,5-dimethyl-thiazol-2-yl)-2 (MTT) and S-diphenyl tetrazolium bromide were purchased from Sigma Chemical Co. (St. Louis, MO, USA). 2, 2Diphenyl-1- Picrylhydrazyl (DPPH) (Sigma-Aldrich) was used for the spectrophotometrical determination of the free radical scavenging activities of the extracts.

\subsection{Plant Materials and Extraction of Oils}

Plant materials, such as the leaves, flowers and seeds from the E. chapmaniana, were collected from several specimens located in the At-Tarmyia (a region $60 \mathrm{~km}$ north-east of Baghdad, Iraq) in 2012. The collected leaf, seed and flower materials were kept at room temperature and left to dry. After air-drying, the plant materials were hydrodistilled for $3 \mathrm{~h}$ by using a Clevenger type apparatus. The resulting oil was collected, preserved in a sealed sample tube and stored until analysis.

\subsection{Gas Chromatography}

The essential oils were analyzed using a Varian Star 3400 (Les Ulis, France) Cx gas chromatograph equipped with a Flame Ionization Detector (FID) and DB-5MS capillary column $(30 \mathrm{~m} \times 0.25 \mathrm{~mm}$, film thickness 0.25 $\mu \mathrm{m})$. The injector and detector temperatures were set at 200 and $270^{\circ} \mathrm{C}$, respectively. The oven temperature was gradually raised from 60 to $260^{\circ} \mathrm{C}$ at a rate of $5^{\circ} \mathrm{C} / \mathrm{min}$. The temperature was held for $15 \mathrm{~min}$ and finally raised to $340^{\circ} \mathrm{C}$ at a rate of $40^{\circ} \mathrm{C} / \mathrm{min}$. Helium (purity $99.99999 \%$ ) was used as the carrier gas at a flow rate of $1 \mathrm{~mL} \mathrm{~min}{ }^{-1}$. The total analysis time was $57 \mathrm{~min}$. About $1.0 \mu \mathrm{L}$ of the diluted sample $(1 / 100$ in petroleum ether, $\mathrm{v} / \mathrm{v}$ ) was injected in the split mode (ratio 1:10). Quantitative data were obtained electronically from the FID area percent data without the correction factors. Peak integration and quantification were performed automatically by using Saturn 2100 Workstation software. The integration of each peak was manually checked and corrected when needed.

\subsection{Gas Chromatography/Mass Spectrometry (GC-MS)}

The essential oils were analyzed in the same conditions as those of GC (column, oven temperature, flow rate of the carrier gas) by using a Varian Star 3400 (Les Ulis, France) gas chromatograph equipped with a Varian Saturn GC/MS/MS 4D mass selective detector in the electron impact mode $(70 \mathrm{eV})$. The injector and MS transfer line temperatures were set at 200 and $300^{\circ} \mathrm{C}$, respectively. MS was adjusted with an emission current of $10 \mu \mathrm{A}$ and an electron multiplier voltage of $1,500 \mathrm{~V}$. The trap temperature was set at $250^{\circ} \mathrm{C}$ and mass scanning was performed from $40 \mathrm{amu}$ to $650 \mathrm{amu}$. The components were identified by comparing their Kovats Indices (KI), by co-injection of standards and by MS experimental data of commercial or literature libraries (NIST 02 version 2.62). Alkanes (C5-C24) were used as reference points in KI calculation. The GC and GC-MS analysis results are given in Table 1. All determinations were performed in duplicate and the average was obtained.

\subsection{Antioxidant Assay}

The DPPH assay was measured by bleaching a purple methanol solution of DPPH (Milliauskas et al., 2004). About $0.5 \mathrm{~mL}$ of $1 \mathrm{mM}$ DPPH solution was added to 3 $\mathrm{mL}$ of various concentrations of sample extracts of $E$. chapmaniana. After $30 \mathrm{~min}$ of incubation at room temperature, the absorbance was obtained against a blank sample at $517 \mathrm{~nm}$. The decrease in the actual absorption was measured against that of the control sample. All experiments were carried out in triplicates and percentage inhibition values were calculated based on the equation:

$\%$ Inhibition $=(\mathrm{A} 0-\mathrm{AT} / \mathrm{A} 0) \times 100$ 
Table 1. Chemical composition of E. chapmaniana extracts identified by GC-MS

\begin{tabular}{|c|c|c|c|c|c|c|}
\hline \multirow[b]{2}{*}{ Compound } & \multirow[b]{2}{*}{ RT min } & \multirow{2}{*}{$\begin{array}{l}\text { Molecular } \\
\text { formula }\end{array}$} & \multirow{2}{*}{$\begin{array}{l}\text { Molecular } \\
\text { weight }\end{array}$} & \multicolumn{3}{|c|}{ Total ion current (\%) } \\
\hline & & & & Leaves & Flowers & Seeds \\
\hline 2,5-Furandione, dihydro-3-methylene- & 3.781 & $\mathrm{C}_{5} \mathrm{H}_{4} \mathrm{O}_{3}$ & 112.083 & 0.26 & - & 1.320 \\
\hline Propanal, 2-methyl- & 11.698 & $\mathrm{C}_{4} \mathrm{H}_{8} \mathrm{O}$ & 72.105 & 0.70 & 0.33 & - \\
\hline $\begin{array}{l}\text { 5,9-dodecadien-2-one, } 6,10 \\
\text {-dimethyl-dodecadien-2-one }\end{array}$ & 11.811 & $\mathrm{C} 14 \mathrm{H}_{24} \mathrm{O}$ & 208.339 & - & - & 1.870 \\
\hline Nonanal dimethyl acetal & 17.508 & $\mathrm{C}_{11} \mathrm{H}_{24} \mathrm{O}_{2}$ & 188.307 & - & 0.51 & - \\
\hline$\alpha$-Pinene & 20.206 & $\mathrm{C}_{10} \mathrm{H}_{16}$ & 136.230 & - & 0.34 & - \\
\hline$\alpha$-phellandrene & 21.920 & $\mathrm{C}_{10} \mathrm{H}_{16}$ & 136.240 & - & 4.16 & - \\
\hline$\beta$-Cymene & 22.508 & $\mathrm{C}_{10} \mathrm{H}_{14}$ & 134.218 & 2.14 & 3.57 & - \\
\hline Eucalyptol & 22.817 & $\mathrm{C}_{10} \mathrm{H}_{18} \mathrm{O}$ & 154.136 & 55.62 & 59.97 & 8.610 \\
\hline$\gamma$-Terpinen & 23.042 & $\mathrm{C}_{10} \mathrm{H}_{16}$ & 136.125 & - & 2.88 & - \\
\hline$\alpha$ - Terpinolen & 23.752 & $\mathrm{C}_{10} \mathrm{H}_{16}$ & 136.234 & - & 0.17 & - \\
\hline Undecane & 23.273 & $\mathrm{C}_{11} \mathrm{H}_{24}$ & 156.188 & 0.79 & 0.47 & 2.770 \\
\hline trans-Pinocarveol & 26.215 & $\mathrm{C}_{10} \mathrm{H}_{16} \mathrm{O}$ & 152.230 & 1.30 & - & - \\
\hline Terpinen-4-ol & 26.627 & $\mathrm{C}_{10} \mathrm{H}_{18} \mathrm{O}$ & 154.249 & 1.91 & 1.97 & - \\
\hline$\alpha$-Terpinol & 27.225 & $\mathrm{C}_{10} \mathrm{H}_{18} \mathrm{O}$ & 154. 249 & 1.98 & - & - \\
\hline Cryptone & 28.148 & $\mathrm{C}_{9} \mathrm{H}_{14} \mathrm{O}$ & 138.206 & 2.23 & - & - \\
\hline Spathulenol & 28.858 & $\mathrm{C}_{15} \mathrm{H}_{24} \mathrm{O}$ & 220.350 & - & 6.84 & - \\
\hline$\beta$-Caryophyllene oxide & 29.517 & $\mathrm{C}_{15} \mathrm{H}_{24} \mathrm{O}$ & 220.350 & - & 2.23 & - \\
\hline p-Cymen-7-ol & 30.916 & $\mathrm{C}_{10} \mathrm{H}_{14} \mathrm{O}$ & 150.217 & 1 & - & - \\
\hline 3-[p-Methoxyphenyl]-5-methylrhodanine & 31.019 & $\mathrm{C}_{11} \mathrm{H}_{11} \mathrm{NO}_{2} \mathrm{~S}_{2}$ & 253.340 & - & - & 15.950 \\
\hline$\gamma$-Muurolene & 32.350 & $\mathrm{C}_{15} \mathrm{H}_{24}$ & 204.351 & - & 0.16 & - \\
\hline exo-2-Hydroxycineole acetate & 32.813 & $\mathrm{C}_{12} \mathrm{H}_{20} \mathrm{O}_{3}$ & 212.285 & - & 0.37 & - \\
\hline$\alpha$-Gurjunene & 34.228 & $\mathrm{C}_{15} \mathrm{H}_{24}$ & 204.351 & - & 1.61 & - \\
\hline 10s,11s-Himachala-3(12),4-diene & 36.067 & $\mathrm{C}_{15} \mathrm{H}_{24}$ & 204.351 & - & 6.59 & - \\
\hline Alloaromadendrene & 37.360 & $\mathrm{C}_{15} \mathrm{H}_{24} \mathrm{O}$ & 220.350 & - & 2.73 & - \\
\hline
\end{tabular}

where, A0 is the absorbance of the control sample (containing all reagents except the test compound) and AT is the absorbance of the test samples.

\subsection{Evaluation of Antibacterial Activity}

E. chapmaniana extracts were tested for antimicrobial activity via the agar well diffusion method against different pathogenic microorganisms, namely, Escherichia coli, Pseudomonas aeruginosa, Klebsiella pneumonia, Proteus volgaris (Gram-negative), Staphylococcus aureus (Gram-positive) and Candida albicans (yeast). Pure bacterial cultures were subcultured on MHA and SDA by using yeast. Each strain was uniformly swabbed onto the individual plates by using sterile cotton swabs. Wells with a diameter of $8 \mathrm{~mm}$ were made on nutrient agar plates by using the gel puncture method. A micropipette was used to pour $50 \mu \mathrm{L}$ of each extract solution onto each well on all plates. After incubation at $37^{\circ} \mathrm{C}$ for $24 \mathrm{~h}$, the zone inhibition diameter was measured in millimeters and was then recorded as mean $\pm \mathrm{SD}$ of the triplicate experiment.

\subsection{Cytotoxicity of HL-60 Cell Line}

The study was performed on human promyeloid leukemia (HL-60) cells. The HL-60 cell line was cultured in RPMI-1640 medium supplemented with $10 \%$ heat-inactivated FBS, $2 \mathrm{mM}$ L-glutamine and 100 $\mathrm{U} / \mathrm{mL}$ of penicillin-streptomycinin in 96-well flatbottom culture plates in a humidified atmosphere of $5 \%$ $\mathrm{CO} 2$ at $37^{\circ} \mathrm{C}$. After $48 \mathrm{~h}$ in the exponentially growing phase, the cells were treated for another $24 \mathrm{~h}$. After incubation, the cell viability was evaluated via the MTT colorimetric technique. About $20 \mu \mathrm{L}$ of the labeling mixture, which consists of $5 \mathrm{mg} \mathrm{mL} \mathrm{m}^{-1}$ MTT in Phosphate-Buffered Saline solution (PBS), was added to each well. Incubation was continued for $4 \mathrm{~h}$ at $37^{\circ} \mathrm{C}$. The culture medium was then removed and $200 \mu \mathrm{L}$ aliquots of Dimethyl Sulfoxide (DMSO) were added to each well to dissolve the formazan crystals, followed by $10 \mathrm{~min}$ of incubation to dissolve the air bubbles. The culture plate was placed on a Biotex Model micro-plate reader and the absorbance was measured at $550 \mathrm{~nm}$. The amount of color produced is directly proportional to the number of viable cells. Each experiment was done in triplicate. The relative cell viability $(\%)$ related to the control wells containing the cell culture medium as a vehicle was calculated as follows:

$$
\% \text { Viability }=\left(\frac{\text { Sample Absorbance }}{\text { Control Absorbance }}\right) \times 100
$$




\subsection{Statistical Analysis}

The grouped data were statistically evaluated using ANOVA with the SPSS/14 software. The values are presented as the mean \pm S.D. of the three replicates of each experiment.

\section{RESULTS}

The total ion chromatograms of leaf, flower and seed extracts from E. chapmaniana were analyzed using a GC-MS instrument and the constituents were quantified via the peak area normalization method.
Table 1 shows the retention indices, molecular weight, total ion current and constituent identity. A total of 22 compounds were identified and the essential oils were the main constituents. Comparing the three extracts, the highest constituent amounts were found in flowers (17 compounds), followed by leaves (10 compounds) and seeds (5 compounds). The essential oils from flowers were constituted by only 15 compounds, followed by leaves with 8 compounds and then by seeds with 2 compounds. The most abundant essential oils of E. chapmaniana are presented in Fig. 1.

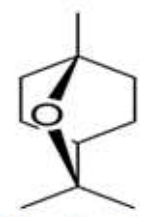

Eucalyptol<smiles>CC1=CCC(C(C)C)C=C1</smiles>

$\alpha$-Phellandrene<smiles>Cc1cccc(C(C)C)c1</smiles><smiles>CC1=CCC(C(C)C)=CC1</smiles>

Y-terpinen<smiles>CC1=CCC(C(C)(C)O)CC1</smiles>

$\alpha$-Terpinol<smiles>CC1=CC[C@](O)(C(C)C)CC1</smiles>

Terpinen-4-01<smiles>C=C1C(O)CC2CC1C2(C)C</smiles>

Trans-pinocarveol<smiles>C=C1CC[C@]2(C)O[C@H]2CC[C@]2(C)[C@@H]1CC2(C)C</smiles>

Spathleno1
$\beta$-Caryophy11ene oxide<smiles>CC1SC(=S)N(c2ccc(O)cc2)C1=O</smiles><smiles>CC/C(C)=C1\[C@@H](CC)CC[C@@]2(C)C(C)(C)[C@@]12C</smiles>

$\alpha$-Gurjunene

3-[p-Methoxypheny1]
-5-methylrhodanine

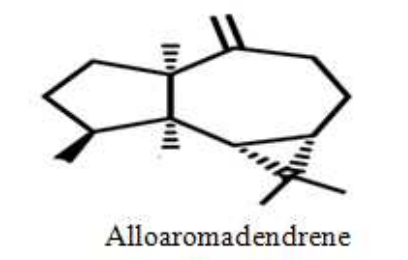

Alloaromadendrene

10s, 11s-Himachala-3(12), 4-diene

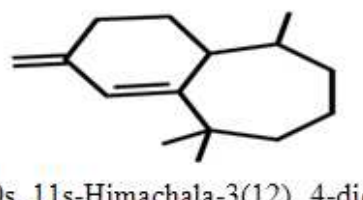

Fig. 1. Structures of the most abundant essential oils identified in E. chapmaniana extracts 
The data presented in Table 1 were based on the information obtained from the GC/MS analyses results in Fig. 2-4, respectively. The E. chapmaniana extracts showed approximately the same TIC profiles, which is caused by the presence of the same substances. Eucalyptol was the predominant compound in flowers (59.9), followed by leaves (55.6) and seeds (8.6\%).

The free radical scavenging effect of $E$. chapmaniana extracts in DPPH was determined and the result is given as a percentage of free radical scavenging activity for four concentrations of 5.0, 50.0, 100.0 and $500.0 \mu \mathrm{g} \mathrm{mL}^{-1}$ of each extract, respectively Table 2 . In general, a concentration-dependent trend was observed and $500 \mu \mathrm{g}$ $\mathrm{mL}^{-1}$ was the best concentration among the tested

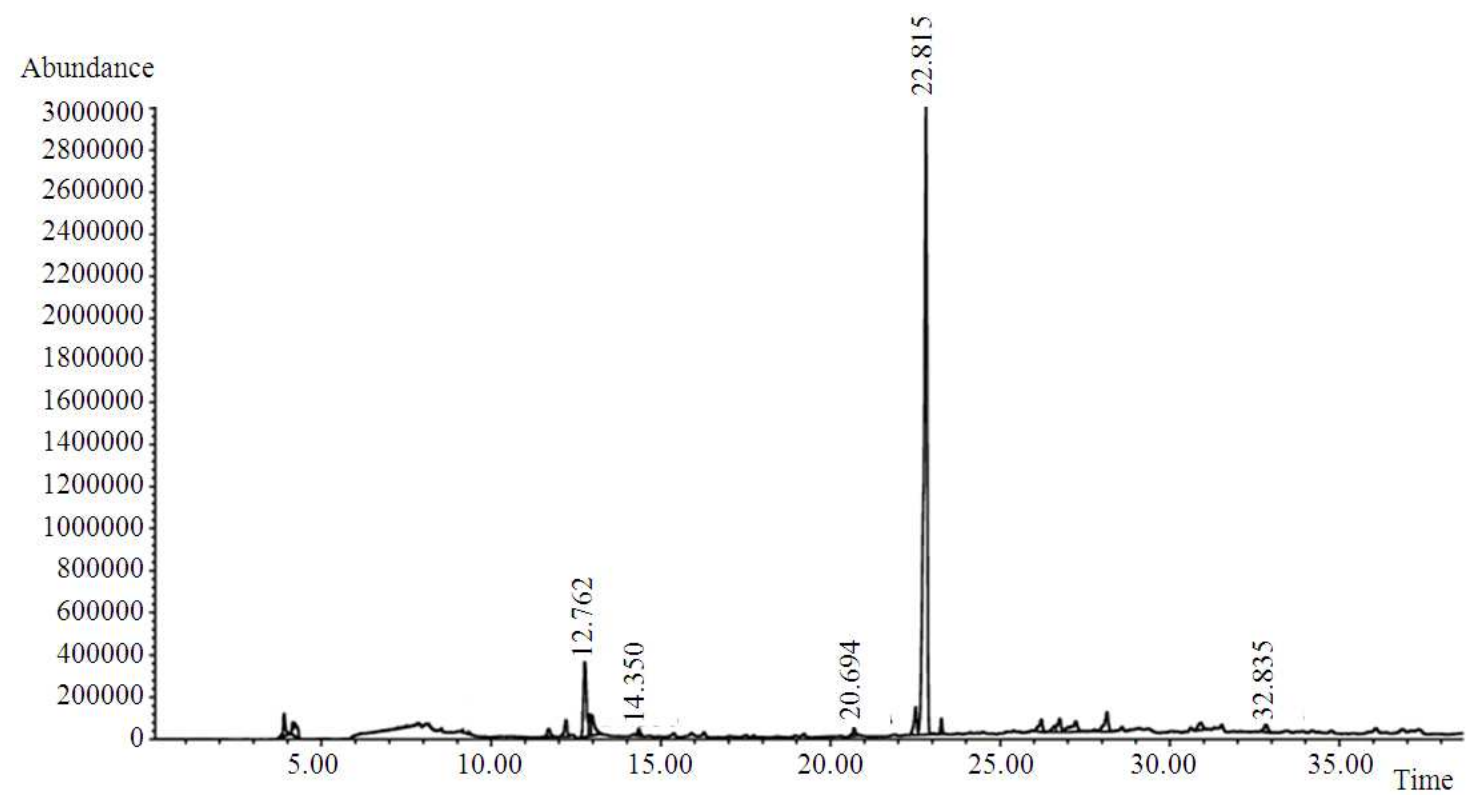

Fig. 2. Total ion chromatogram of leaf extract of E. chapmaniana grown in Iraq

Table 2. DPPH free radical scavenging activity of leaves, flowers and seeds extracts of $E$. chapmaniana grown in Iraq $\%$ Scavenging activity of $E$. chapmaniana extracts*

\begin{tabular}{llll} 
& & $50 \mu \mathrm{g} \mathrm{mL}^{-1}$ & $100 \mu \mathrm{gL}^{-1}$ \\
\hline Leaves & $5 \mu \mathrm{g} \mathrm{mL}^{-1}$ & $82.3 \pm 0.8$ & $86.2 \pm 0.7$ \\
Flowers & $50.3 \pm 0.6$ & $81.5 \pm 0.7$ & $90.2 \pm 0.5$ \\
Seeds & $50.4 \pm 0.8$ & $60.1 \pm 0.8$ & $75.1 \pm 0.2$ \\
\hline
\end{tabular}

*; Scavenging activity are mean values of three determinants

Table 3. Size of the inhibition zone for E. chapmaniana extracts against the tested microorganisms

\begin{tabular}{|c|c|c|c|c|c|c|}
\hline \multirow[b]{2}{*}{ Samples } & \multicolumn{6}{|c|}{ Zone of inhibition $(\mathrm{mm})^{*}$} \\
\hline & E. coli & P. aeruginosa & K. pneumonia & P. volgaris & S. aureus & C. albicans \\
\hline Leaves & $17.9 \pm 1.5$ & $18.6 \pm 1.6$ & $17.5 \pm 1.0$ & $17.4 \pm 1.7$ & $20.2 \pm 1.5$ & $19.3 \pm 1.2$ \\
\hline Flowers & $18.8 \pm 1.2$ & $19.8 \pm 1.6$ & $17.3 \pm 1.6$ & $18.4 \pm 1.3$ & $20.6 \pm 1.9$ & $21.8 \pm 1.5$ \\
\hline Seeds & $15.2 \pm 1.3$ & $16.3 \pm 1.2$ & $17.7 \pm 1.9$ & $17.2 \pm 1.5$ & $19.0 \pm 1.4$ & $16.8 \pm 1.6$ \\
\hline
\end{tabular}

*; Zone of inhibitions are mean values of three determinants 


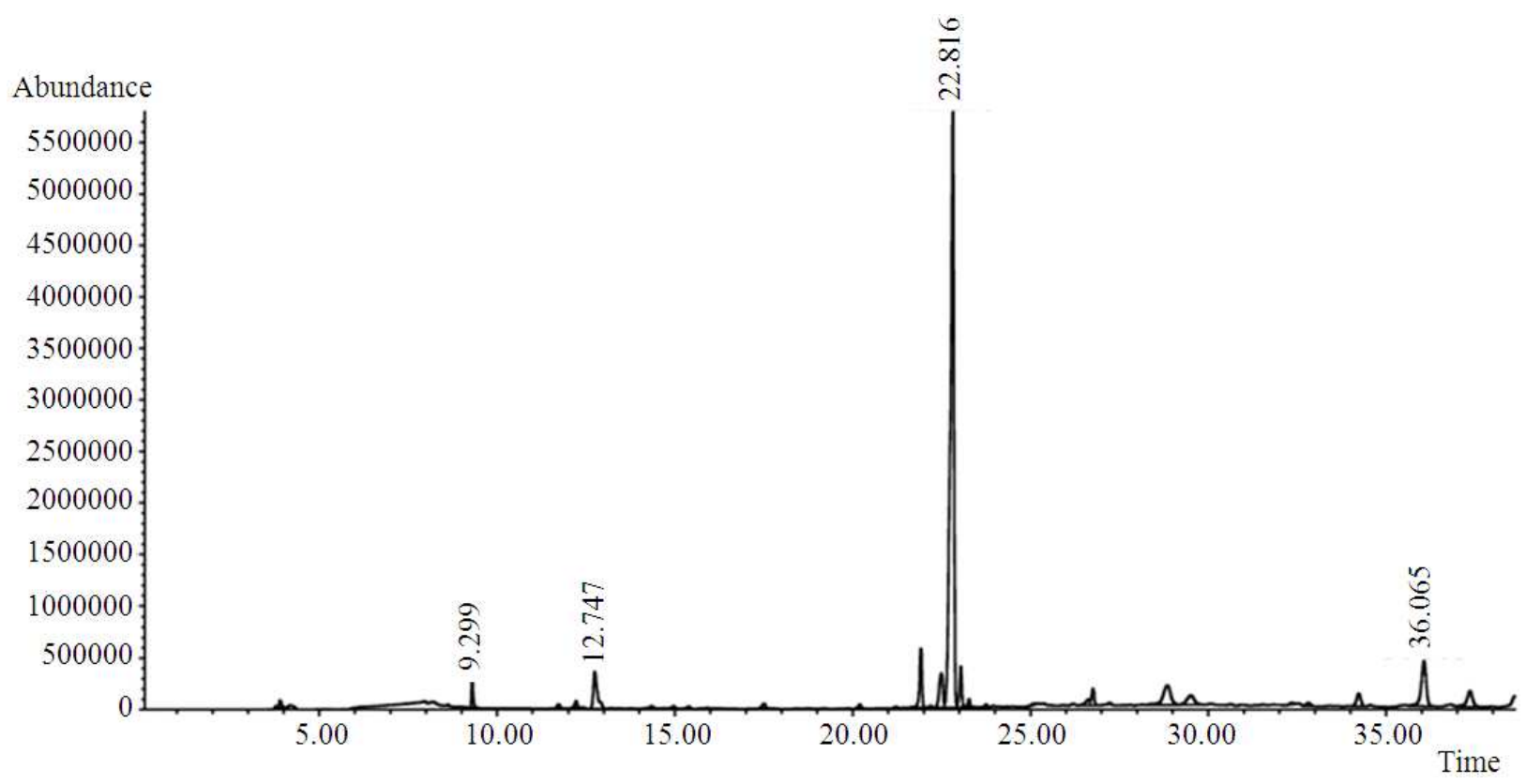

Fig. 3. Total ion chromatogram of flower extract of E. chapmaniana grown in Iraq

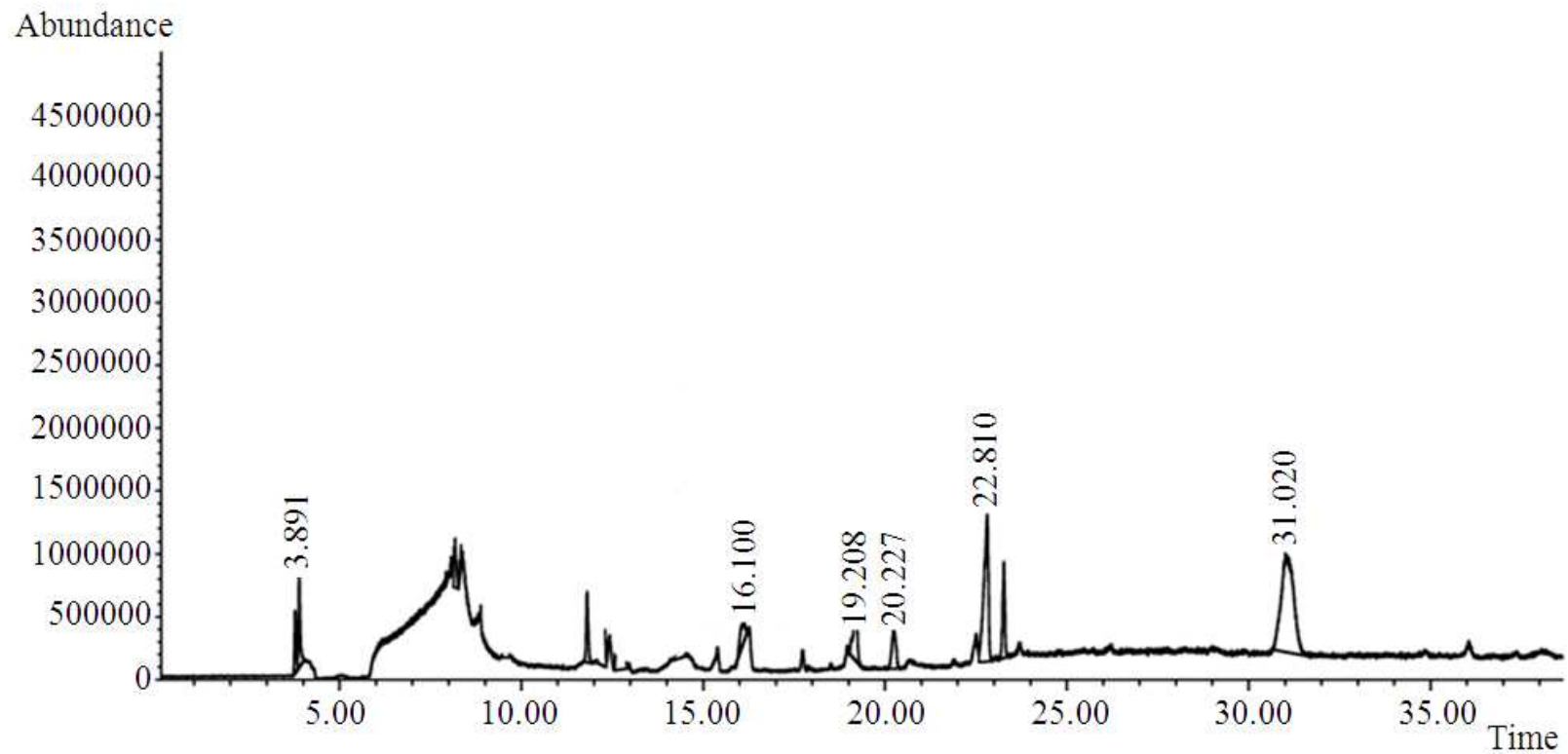

Fig. 4. Total ion chromatogram of seed extract of E. chapmaniana grown in Iraq

The cytotoxic activity of flower extracts on the HL-60 cell line was further studied to evaluate the dose-related cytotoxic activities. The inhibitory effects were determined $24 \mathrm{~h}$ later and the results are presented in Fig. 5. The flower extracts $(5,10,20$,
40, 60, and $80 \mu \mathrm{g} \quad \mathrm{mL}^{-1}$ ) showed significant cytotoxicity on the HL-60 cell line. In addition, the $80 \mu \mathrm{g} \mathrm{mL} \mathrm{mL}^{-1}$ concentration was more potent, which showed $90 \%$ potency compared with the control sample Fig. 5. 


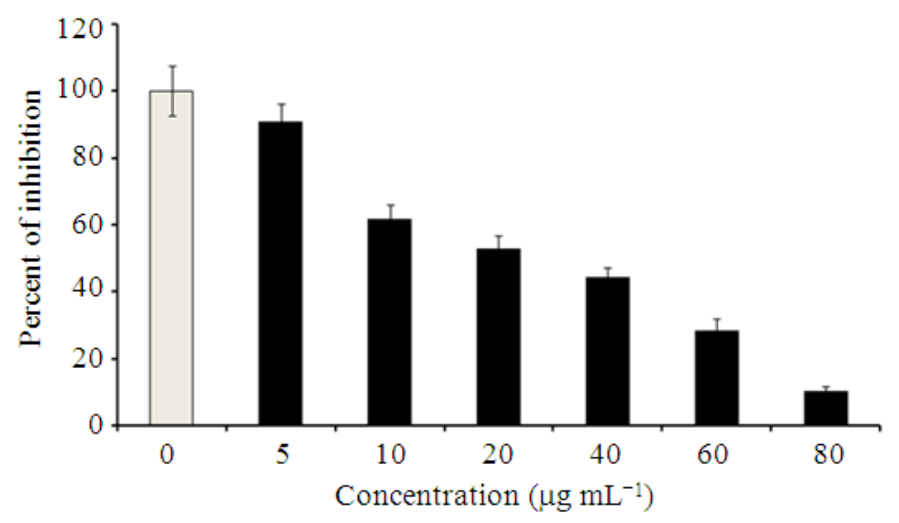

Fig. 5. Antiproliferative activity of flowers extract at different concentrations on HL-60 cells. Data is expressed as the mean \pm S.D. of data obtained from triplicate experiment

\section{DISCUSSION}

The extracts obtained from leaves, seeds and flowers of E. chapmaniana exhibited cytotoxic activities and inhibited the growth of yeast and bacteria. Likewise, the antioxidant activity was evaluated by the ability of the essential oils to scavenge DPPH radical in methanol. The results showed that the essential oils exhibited a strong free radical scavenging activity. This study is the first to report on the antioxidant, antimicrobial and cytotoxic activities of extracts from leaves, seeds and flowers of $E$. chapmaniana grown in Iraq.

Chemical composition analysis of the essential oils of leaves and flowers of E. chapmaniana showed that this species is rich in essential oils, which are responsible for the antioxidant activity and other beneficial properties of Eucalyptus. Based on previous studies, the essential oils were identified from various Eucalyptus extracts. However, these studies did not include E. chapmaniana. The chemical composition of the essential oils of different parts of other species of Eucalyptus can vary widely (Giamakis et al., 2001; Tsiri et al., 2003; Marzoug et al., 2011).

The E. chapmaniana extracts showed approximately the same TIC profiles, which is caused by the presence of the same substances. However, the full scan spectra and the corresponding MS/MS spectra (not shown) indicate a high value of Eucalyptol in both flower and leaf extracts. By contrast, the seed extracts showed fewer value. Eucalyptol was also found in majority of other species of Eucalyptus, such as E. staigeriana (Gilles et al., 2010), E. globules (Maciel et al., 2010; Tyagi and Malik, 2011) and E. urophylla (Cheng et al., 2009). Nevertheless, the main component in other species of Eucalyptus can be a different compound, such as piperitone (E. dives), (E)methyl cinnamate (E. olida) (Gilles et al., 2010), apinene (E. camaldulensis) (Cheng et al., 2009), limonene (E. staigeriana), $\beta$-citronellal (E. citriodora) (Maciel et al., 2010), or p-cymene (E. tereticorni) (Toloza et al., 2006). The chemical composition of essential oil is affected by several factors, such as species, geographical location, harvest time, plant part and isolation method (Cimanga et al., 2002; Penalver et al., 2005; Marzoug et al., 2011).

The E. chapmaniana variety used in this study is different from other Eucalyptus species, in terms of the chemical composition of essential oils, which makes the results obtained interesting. In addition, the essential oils of the Eucalyptus species possess important biological characteristics, including diaphoretic, disinfectant, anti-malarial, antiseptic, analgesic, anti-inflammatory, antimicrobial, anticancer and antioxidant properties (Lee and Shibamoto, 2001; Cimanga et al., 2002; Ashour, 2008).

The results of the current study showed that different extracts of E. chapmaniana exhibited different antioxidant activities. In the presence of antioxidants, the DPPH radical is converted to DPPH-H and the characteristic purple color lightens. This result was caused by the different amounts of the constituents (Sulaiman et al., 2013). Essential oils are complex mixtures that are composed of numerous compounds and each of the constituent contributes to the biological effects of these oils (Buchbauer, 2000). Moderate invitro antioxidant activities of terpinene and its derivatives, such as terpinen-4-ol, have been documented (Kim et al., 2004). However, pinene and cymene possess no significant or appreciable 
antioxidant activities (Lee and Shibamoto, 2001). The strong antioxidant properties of essential oils are due to their phenolic constituents, such as thymol, cavacrol and probably 1, 8-cineole, which has moderate DPPH radical scavenging activity as reported by (Edris, 2007).

The present study reports the broad spectrum of antimicrobial activity of E. chapmaniana flower, seed and leaf extracts. The ability of Eucalyptus oils to inhibit the growth of both Gram-positive and Gramnegative bacteria, as well as of fungus, is in agreement with previous reports on the antibacterial activity of other Eucalyptus species (Tuberoso et al., 2006; Gaudreau et al., 2007; Sartorelli et al., 2007). The present study also reported the susceptibility of both Gram-positive and Gram-negative bacteria towards $E$. chapmaniana extracts. The susceptibility of Grampositive bacteria is in agreement to previously reported results on a wide variety of South American (Paz et al., 1995), African (Vlietinck et al., 1995), Australian (Palombo and Semple, 2001) and Asian (Jeyakumar et al., 2011) plant oils.

The present study differed from previous studies because the latter only focused on essential oils prepared from leaves, which may not represent the full antimicrobial pattern of essential oils obtained from other parts of the plant (flowers, seeds). The essential oil content of different plants varies (together with the biologically active compounds contained) depending on the plant's part (flower, seeds, leaves, whole plant) and variety, as well as on the harvest season and cultivation method (Cimanga et al., 2002; Ramezani et al., 2002; Sartorelli et al., 2007).

Flower extracts of E. chapmaniana, which had the highest levels of Eucalyptol, were more active against the tested microorganisms than other extracts. The results are in agreement with those of previous studies, where Eucalyptol had strong antimicrobial properties against numerous important pathogens (Bakkali et al., 2008; Rosato et al., 2007). The activity of this chemical compound may be increased by other minor components. However, based on the chemical composition of essential oils in the samples, the antimicrobial activity was not related to a high content of a single chemical compound, but rather to synergic effects of major and minor components (Elaissi et al., 2012).

The MTT results of the essential oils from flowers on the HL-60 cell line showed a concentrationdependent toxicity, which suggested that the product is more toxic to cancer cells. MTT reduction is usually conducted to study the mitochondrial/nonmitochondrial dehydrogenase activity as a cytotoxic test for a variety of chemical compounds. Therefore, volatile oils from flowers of $E$. chapmaniana can potentially change the mitochondrial enzymatic activity and initiate a preliminary injury, which leads to cell death. Furthermore, essential oils were reported to cause damage in the mitochondrial membrane because they provoke mitochondrial membrane depolarization by decreasing the membrane potential (Vercesi et al., 1997).

Likewise, the membrane fluidity is altered, which becomes abnormally permeable. Additional mechanisms were previously reported on the cytotoxic effect of volatile oils from young and adult leaves of E. benthamii (DollBoscardin et al., 2012). Studies on essential oils and their individual volatile components have caused researchers to shift their attention to cancer treatment. A number of articles have investigated the effect of essential oil against a variety of human cancer cell lines. De Sousa et al. (2004) verified that the essential oils of lemon balm (Melissa officinalis L.) showed a cytotoxic activity against specific human cancer cell lines (A549, MCF-7, Caco-2, HL-60 and K562) and a mouse cell line (B16F10). Other studies of plant extracts revieled a potential toxicity against different cell lines (Naphong et al., 2013; Mahiwan et al., 2013). Regarding the cytotoxic effect of essential Eucalyptus oils, information is remarkably restricted. Ashour (2008) showed the cytotoxic activities of volatile oils and extracts from stems, leaves and flowers of E. sideroxylon and E. torquata against the human breast adenocarcinoma cell line (MCF7). The essential oil extracted from stems of $E$. torquata exhibited the best cytotoxicity against MCF7 cells, followed by volatile oils from E. torquata and E. sideroxylon leaves.

\section{CONCLUSION}

In conclusion, this study demonstrates, for the first time, the antioxidant, antimicrobial and cytotoxic effects of the essential oils of E. chapmaniana grown in Iraq. $E$. chapmaniana is a species that could be employed a rich source of Eucalptol especialy in flowers and leaves. Moreover, the obtained cytotoxic results support an experimental basis that the essential oils of $E$. chapmaniana lead to cell death. The antimicrobial and cytotoxic activities of E. chapmaniana extracts are positively correlated with oil composition and antioxidant activity. These data can also pave the way for the development of future therapeutic strategies to protect humans from deleterious oxidative processes and cancer. Although the essential oils obtained from the Eucalyptus species have been used in folk medicine, their use must be cautioned because systemic toxicity 
may occur from ingestion or topical application at higher doses. The probable lethal dose of pure essential oils of Eucalyptus spp. for an adult is in the range of $0.05 \mathrm{~mL}$ to $0.5 \mathrm{~mL} \mathrm{~kg}$ and severe poisoning has occurred in children after ingestion of 4 to $5 \mathrm{~mL}$ (Foggie, 2011; Doll-Boscardin et al., 2012). This limitation in the dosage of essential oils of Eucalyptus spp needs further investigation, to assess the real advantages of their use. Future developments of this work include the purification and study of active oil compounds, as a mean to better understand the relationship between traditional therapy and current medicinal practice.

\section{REFERENCES}

Arts, I.C. and P.C. Hollman, 2005. Polyphenols and disease risk in epidemiologic studies. Am. J. Clin. Nutr., 81: 317-325. PMID: 15640497

Ashour, H.M., 2008. Antibacterial, antifungal and anticancer activities of volatile oils and extracts from stems, leaves and flowers of Eucalyptus sideroxylon and Eucalyptus torquata. Canc. Biol. Ther., 7: 399-403. PMID: 18075306

Bakkali, F., S. Averbeck, D. Averbeck and M. Idaomar, 2008. Biological effects of essential oils-a review. Food Chem. Toxicol., 46: 446-475. PMID: 17996351

Batish, D.R., H.P. Singh, R.K. Kohli and S. Kaur, 2008. Eucalyptus essential oil as a natural pesticide. Forest Ecol. Manage., 256: 2166-2174.

Benyahia, S., S. Benayache, F. Benayache, F. Leon and J. Quintana et al., 2005. Cladocalol, a pentacyclic 28-nor-triterpene from Eucalyptus cladocalyx with cytotoxic activity. Phytochemistry, 66: 627-632. PMID: 15771880

Buchbauer, G., 2000. The detailed analysis of essential oils leads to the understanding of their properties. Perfumer Flavorist, 25: 64-67.

Cheng, S.S., C.G. Huang, Y.J. Chen, J.J. Yu and W.J. Chen et al., 2009. Chemical compositions and larvicidal activities of leaf essential oils from two eucalyptus species. Bioresource Technol., 100: 452456. PMID: 18396398

Cimanga, K., K. Kambu, L. Tona, S. Apers and D.T. Bruyne et al., 2002. Correlation between chemical composition and antibacterial activity of essential oils of some aromatic medicinal plants growing in the democratic republic of Congo. J. Ethnopharmacol., 79: 213-220. PMID: 11801384
De Sousa, A.C., D.S. Alviano, A.F. Blank, P.B. Alves and C.S. Alviano et al., 2004. Melissa officinalis L. Essential oil: Antitumoral and antioxidant activities. J. Agric. Food Chem., 52: 2485-2489. PMID: 15142347

Doll-Boscardin, P.M., A. Sartoratto, M.B.H. Sales, P.D.J. Paula and T. Nakashima et al., 2012. In vitro cytotoxic potential of essential oils of Eucalyptus benthamii and its related terpenes on tumor cell lines. Evid. Based Compl. Alternat. Med. DOI: $10.1155 / 2012 / 342652$

Edris, A.E., 2007. Pharmaceutical and therapeutic potentials of essential oils and their individual volatile constituents: A review. Phytother. Res., 21: 308-323. PMID: 17199238

Elaissi, A., Z. Rouis, N.A. Salem, S. Mabrouk and B.Y. Salem and K.B. Salah et al., 2012. Chemical composition of 8 eucalyptus species' essential oils and the evaluation of their antibacterial, antifungal and antiviral activities. BMC Compl. Altern. Med. PMID: 2274253

Foggie, W.E., 2011. Eucalyptus oil poisoning. Br. Med. J., 1: 359-360.

Gaudreau, C., Y. Girouard, L. Ringuette and C. Tsimiklis, 2007. Comparison of disc diffusion and agar dilution methods for erythromycin and ciprofloxacin susceptibility testing of Campylobacter jejuni subsp. Jejuni. J. Antimicrob. Chemother., 51: 1524-1526. DOI: 10.1128/AAC.00905-06

Giamakis, A., O. Kretsi, I. Chinou and C.G. Spyropoulos, 2001. Eucalyptus camaldulensis: Volatiles from immature flowers and high production of 1,8 -cineole and $\beta$-pinene by in vitro cultures. Phytochemistry, 58: 351-335. DOI: 10.1016/S0031-9422(01)00193-5

Gilles, M., J. Zhao, M. An and S. Agboola, 2010. Chemical composition and antimicrobial properties of essential oils of three Australian Eucalyptus species. Food Chem., 119: 731-737. DOI: 10.1016/j.foodchem.2009.07.021

Jeyakumar, E., R. Lawrence and T. Pal, 2011. Comparative evaluation in the efficacy of peppermint (Mentha piperita) oil with standards antibiotics against selected bacterial pathogens. Asian Pac. J. Trop. Biomed., 1: S253-S257. DOI: 10.1016/S2221-1691(11)60165-2 
Jung, T., A. Hohn, B. Catalgol and T. Grune, 2009. Agerelated differences in oxidative protein-damage in young and senescent fibroblasts. Arch. Biochem. Biophys., 483: 127-135. PMID: 19135972

Kim, H., C. Wu, F. Chen, X. Wang and H. Chung et al., 2004. Evaluation of antioxidant activity of tea tree (Melaleuca alternifolia) oil and its components. J. Agric. Food Chem., 52: 2849-2854. PMID: 15137824

Lee, K.G. and T. Shibamoto, 2001. Antioxidant activities of volatile components isolated from Eucalyptus species. J. Sci. Food Agric., 81: 1573-1597. DOI: 10.1002/jsfa.980

Maciel, M.V., S.M. Morais, C.M.L. Bevilaqua, R.A. Silva and R.S. Barros et al., 2010. Chemical composition of Eucalyptus spp. essential oils and their insecticidal effects on Lutzomyia longipalpis. Vet. Parasitol., 167: 1-7. PMID: 19896276

Mahiwan, C., M. Buayairaksa, N. Nuntasaen, P. Meepowpan and W. Pompimon, 2013. Potential cancer chemopreventive activity of styryllactones from Goniothalamus marcanii. Am. J. Applied Sci., 10: 112-116. DOI:10.3844/ajassp.2013.112.116

Marzoug, H.N.B., M. Romdhane, A. Lebrihi, F. Mathieu and F. Couderc et al., 2011. Eucalyptus oleosa essential oils: Chemical composition and antimicrobial and antioxidant activities of the oils from different plant parts (stems, leaves, flowers and fruits). Molecules, 16: 1695-1709. PMID: 21330958

Milliauskas, G., P.R. Venskutonis and T.A. Van-Beek, 2004. Screening of radical scavenging activity of some medicinal and aromatic plant extracts. Food Chem., 85: 231-237. DOI: 10.1016/j.foodchem.2003.05.007

Naphong, C., W. Pompimon and P. Sombutsiri, 2013. Anticancer activity of isolated chemical constituents from Miliusa smithiae. Am. J. Applied Sci., 10: 787792.DOI: 10.3844/ajassp.2013.787.792

Oyedeji, A.O., O.N. Olawore, O. Ekundayo and W.A. Koenig, 1999. Volatile leaf oil constituents of three Eucalyptus species from Nigeria. Flav. Fragr. J., 14: 241-244. DOI: 10.1002/(SICI)1099-1026(199907

Packer, L., E. Cadenas and K.J.A. Davies, 2008. Free radicals and exercise: An introduction. Free Radic. Biol. Med., 44: 123-125. DOI: 10.1016/j.freeradbiomed.2007.05.031
Palombo, E.A. and S.J. Semple, 2001. Antibacterial activity of traditional Australian medicinal plants. J. Ethnopharmacol., 77: 151-157. PMID: 11535358

Paz, E.A., M.P. Cerdeiras, J. Fernandez, F. Ferreira and P. Moyna et al., 1995. Screening of Uruguayan medicinal plants for antimicrobial activity. J. Ethnopharm., 45: 67-70. PMID: 7739229

Penalver, P., B. Huerta, C. Borge, R. Astorga and R. Romero et al., 2005. Antimicrobial activity of five essential oils against origin strains of the Enterobacteriaceae family. APMIS, 113: 1-6. PMID: 15676008

Ramezani, H., H.P. Singh, D.R. Batish and R.K. Kohli, 2002. Antifungal activity of the volatile oil of eucalyptus citriodora. Fitoterapia, 73: 261-262. PMID: 12048022

Rosato, A., C. Vitali, D.N. Laurentis, D. Armenise and M. Milillo, 2007. Antibacterial effect of some essential oils administered alone or in combination with Norfloxacin. Phytomedicine, 14: 727-732. PMID: 17303397

Salari, M.H., G. Amine, M.H. Shirazi, R. Hafezi and M. Mohammadypour, 2006. Antibacterial effects of Eucalyptus globulus leaf extract on pathogenic bacteria isolated from specimens of patients with respiratory tract disorders. Clin. Microbiol. Infect., 12: 194-196. PMID: 16441463

Sartorelli, P., A.D. Marquioreto, A. Amaral-Baroli, M.E. Lima and P.R. Moreno, 2007. Chemical composition and antimicrobial activity of the essential oils from two species of Eucalyptus. Phytother. Res., 21: 231-233. PMID: 17154233

Sulaiman, G.M., N.N. Hussien, T.R. Marzoog and H.A. Awad, 2013. Phenolic content, antioxidant, antimicrobial and cytotoxic activities of ethanolic extract of Salix alba. Am. J. Biochem. Biotechnol., 9: 41-46. DOI: 10.3844/ajbbsp.2013.41.46

Takahashi, T., R. Kokubo and M. Sakaino, 2004. Antimicrobial activities of Eucalyptus leaf extracts and flavonoids from Eucalyptus maculata. Lett. Applied Microbial., 39: 60-64. PMID: 15189289

Toloza, A.C., J. Zygadlo, G. Mougabure, F. Biurrun and E. Zerba et al., 2006. Fumigant and repellent properties of essential oils and component compounds against permethrin-resistant Pediculus humanus capitis (Anoplura: Pediculidae) from Argentina. J. Med. Entomol., 3: 889-895. PMID: 17017225 
Tsiri, D., O. Kretsi, I.B. Chinou and C.G. Spyropoulos, 2003. Composition of fruit volatiles and annual changes in the volatiles of leaves of Eucalyptus camaldulensis dehn. growing in Greece. Flavour Fragr. J., 18: 244-247. DOI: 10.1002/ffj.1220

Tuberoso, C.I.G., A. Barra, A. Angioni, E. Sarritzu and F.M. Pirisi, 2006. Chemical composition of volatiles in sardinian myrtle (Myrtus communis L.) alcoholic extracts and essential oils. J. Agric. Food Chem., 54: 1420-1426. PMID: 16478269

Tyagi, A.K. and A. Malik, 2011. Antimicrobial potential and chemical composition of Eucalyptusglobulus oil in liquid and vapour phase against food spoilage microorganisms. Food Chem., 126: 228-235. DOI: 10.1016/j.foodchem.2010.11.002

Vercesi, A. E., A.J. Kowaltowski, M.T. Grijalba, A.R. Meinicke and R.F. Castilho, 1997. The role of reactive oxygen species in mitochondrial permeability transition. Biosci. Rep., 17: 43-52. PMID: 9171920
Vlietinck, A.J., V.L. Hoof, J. Totte, A. Lasure and V.B.D. Rwangabo et al., 1995. Screening of hundred rwandese medicinal plants for antimicrobial and antiviral properties. J. Ethnopharmacol., 46: 31-47. PMID: 7475121

Wells, P.G., G.P. McCallum, C.S. Chen, J.T. Henderson and C.J.J. Lee et al., 2009. Oxidative stress in developmental origins of disease: Teratogenesis, neurodevelopmental deficits and cancer. Toxicol. Sci., 108: 4-18. PMID: 19126598

Wilson, P.G., M.M. O'Brien, P.A. Gadek and C.J. Quinn, 2001. Myrtaceae revisited: A reassessment of infrafamilial groups. Am. J. Bot., 88: 2013-2025. PMID: 21669634 